\section{JECl Journal of Educational Chemistry}

Journal of Educational Chemistry (1 (2), 2019, 82-91)

Website: http://www.journal.walisongo.ac.id/index.php/jec

ISSN 2715-3029 (p) 2685-4880 (e)

DOI: $10.21580 /$ jec.2019.1.2.4357

\title{
Efektivitas Penggunaan Multimedia Pembelajaran Berbasis Multi Level Representasi (MLR) Untuk Meningkatkan Hasil Belajar Peserta Didik Pada Materi Sistem Koloid Kelas XI MAN Kendal
}

\author{
Indah Dwi Astuti, Mulyatun ${ }^{2}$ \\ Pendidikan Kimia, Universitas Islam Negeri Walisongo Semarang \\ 1E-mail : indahda@gmail.com
}

\begin{abstract}
This research aimed to understand the effectiveness of the use of multimedia learning based MLR on the material of colloidal system. Research conducted study is an experiment with the form of Pretestposstest Control Group Design with the sampling in clusters of random sampling. The value of average learning outcomes obtained from a experiment class and control class in a row is 74,85 with percentage of completeness $71 \%$ and 65,97 with the percentage of completeness 33\% . Based on results test of t-test on $\alpha$ $=5 \%$ and $d k=56$ obtained $t_{\text {count }}>t_{\text {tabel }}=4,475>2,003$, so to be concluded that there a difference the average of learning outcomes between classes experiment and control. Futher tests from the results of the analysis of the right side, obtained $t_{\text {count }}>t_{\text {tabel }}=4,475>1,672$ with $d k=57$ and at $\alpha=5 \%$. The results of this research can be concluded that learning chemistry using multimedia based on MLR learning on colloidal material is effectively applied to learning chemistry, and can improve learning outcomes of class XI MIPA students in MAN Kendal.
\end{abstract}

Keywords: learning media, multi level representation (MLR), learning outcomes, colloidal system

82

Copyright (C) 2019 JEC | ISSN 2715-3029 (p) 2685-4880 (e)

Volume 1, Nomor 2, 2019 


\begin{abstract}
Abstrak
Penelitian ini bertujuan untuk mengetahui efektivitas penggunaan pembelajaran multimedia berbasis MLR pada materi sistem koloid. Penelitian yang dilakukan adalah penelitian eksperimen dengan bentuk Pretest-posstest Control Group Design dengan pengambilan sampel dalam kelompok cluster random sampling. Nilai rata-rata hasil belajar yang diperoleh dari kelas eksperimen dan kelas kontrol berturut-turut adalah 74,85 dengan persentase ketuntasan 71\% dan 65,97 dengan persentase ketuntasan 33\%. Berdasarkan hasil uji t-test pada $=5 \%$ dan $d k=56$ diperoleh $t_{\text {hitung }}>t_{\text {tabel }}=4,475>$ 2,003, sehingga dapat disimpulkan bahwa terdapat perbedaan rata-rata hasil belajar antara kelas eksperimen dan kontrol. Selanjutnya dari hasil analisis sisi kanan, diperoleh $t_{\text {hitung }}>t_{\text {tabel }}=4,475>1,672$ dengan $\mathrm{dk}=57$ dan pada $=5 \%$. Hasil penelitian ini dapat disimpulkan bahwa pembelajaran kimia menggunakan multimedia berbasis pembelajaran MLR pada materi koloid efektif diterapkan pada pembelajaran kimia, dan dapat meningkatkan hasil belajar siswa kelas XI MIPA di MAN Kendal.
\end{abstract}

Kata Kunci: media pembelajaran, multi level representasi (MLR), hasil belajar, sistem koloid

\title{
Pendahuluan
}

Ilmu kimia adalah cabang ilmu pengetahuan alam (IPA) yang mempelajari kajian tentang struktur, komposisi, sifat dan perubahan materi serta energi yang menyertai perubahan tersebut. Ilmu kimia memiliki beberapa karakteristik yang membedakan dengan ilmu lain (Depdiknas, 2003). Menurut Sunyono (2012), karakteristik penting ilmu kimia mencakup interaksi materi pada tingkatan makroskopik, mikroskopik, dan simbolik. Ketiga tingkatan tersebut yang membuat sebagian besar pelajaran kimia menjadi sulit untuk dipahami oleh peserta didik.

Banyak konsep kimia dengan berbagai karakteristik diantaranya bersifat abstrak yang mencakup interaksi materi pada tingkatan makroskopik, mikroskopik, dan simbolik, menjadikan peserta didik membutuhkan waktu lama untuk memahami materi kimia yang diajarkan. Kesulitan peserta didik dalam memahami ketiga level fenomena sains tersebut disebabkan karena dalam proses pembelajaran peserta didik cenderung menerima pelajaran kimia yang hanya melihat buku teks saja, sehingga sering kali mengakibatkan hasil belajar peserta didik menjadi rendah. Menurut Herawati (2013), pada umumnya pembelajaran kimia saat ini hanya mengajarkan pada level makroskopik saja, sedangkan level sub mikroskopik dan simbolik hanya dalam bentuk hafalan yang abstrak akibatnya peserta didik tidak mampu membayangkan bagaimana proses dan struktur suatu zat yang mengalami reaksi. Oleh karena itu, karakteristik ilmu kimia harus dipahami dengan memperhatikan keterhubungan tiga level representasi, maka media pembelajaran atau bahan ajar yang digunakan seharusnya telah memenuhi kriteria tersebut. 
Berdasarkan permasalahan di atas salah satu komponen penting yang mempengaruhi dalam proses pembelajaran dan hasil belajar peserta didik adalah media pembelajaran. Media pembelajaran yang dapat menunjang pemahaman konsep yang memperhatikan keterhubungan tiga level representasi tersebut adalah media pembelajaran Multi Level Represtasi (MLR). Hal ini, bertujuan untuk mencapai pembelajaran yang efektif dan meningkatkan hasil belajar peserta didik. Menurut Johnstone, kemampuan menyelesaikan masalah kimia yang dikembangkan saat ini mengarahkan pada fenomena kimia pada tiga level representasi yang berbeda, yakni makroskopik, simbolik, submikroskopik, dan harus diajarkan secara eksplisit hubungan antara level representasi yang satu dengan yang lainnya (Mujakir, 2017).

Dari hasil wawancara dan observasi dengan guru pengampu mata pelajaran kimia yaitu Ibu Juni Purwanti Kusumastuti, S.Pd pada tanggal 20 Mei 2019 di MAN Kendal, diperoleh data bahwa materi kimia yang sulit dipahami peserta didik adalah materi kimia yang mencakup hal-hal abstrak, hafalan dan hitungan. Penggunaan LKS di MAN Kendal memiliki beberapa kekurangan. Kekurangan yang pertama yaitu tidak terdapat petunjuk belajar dalam LKS. Dengan tidak adanya petunjuk belajar, mengakibatkan peserta didik tidak dapat belajar secara mandiri. Kekurangan kedua yaitu LKS atau buku teks yang digunakan masih berada pada dua level reprsentasi yaitu makroskopik dan simbolik, sedangkan tingkatan mikroskopik masih belum diterapkan pada LKS atau buku teks tersebut. Hal tersebut ternyata dapat menghambat kemampuan peserta didik dalam

84

Copyright (C) 2019 JEC | ISSN 2715-3029 (p) 2685-4880 (e)

Volume 1, Nomor 2, 2019 memecahkan masalah-masalah kimia pada tingkatan yang lainnya. Akibatnya hasil belajar peserta didik pada materi kimia rendah dilihat dari nilai UTS yang diperoleh sekitar 70\% nilai masih di bawah KKM.

Salah satu sarana yang baik digunakan dalam meningkatkan hasil belajar peserta didik serta efektif dalam menguasai konsep materi yang digunakan yaitu dengan menggunakan multimedia pembelajaran berbasis Multi Level Representasi (MLR), karena media pembelajaran berbasis MLR ini menunjang pemahaman konsep yang memperhatikan keterhubungan tiga level representasi yaitu makroskopik, mikroskopik dan simbolik.

Demikian halnya yang terjadi di MAN Kendal, berdasarkan hasil penelitian sebelumnya yang dilakukan oleh Nadhifah, sebanyak 68\% dari peserta didik mendapat nilai yang kurang dari KKM karena mereka menganggap pelajaran kimia sulit dan guru juga lebih sering menggunakan metode ceramah dan diskusi dalam proses pembelajarannya. Terkait hal tersebut, hasil dari penelitian sebelumnya membenarkan bahwa ketika diberikan soal latihan atau ujian peserta didik hanya sebanyak $32 \%$ yang bisa menjawab dan $68 \%$ nya lagi belum bisa menjawab soal-soal yang diberikan. Setelah diterapkannya multimedia pembelajaran berbasis Multi Level Representasi (MLR) untuk kelas kecil yang terdiri dari 9 peserta didik didapatkan nilai $\mathrm{N}$-gain sebesar 0,61 dengan kategori sedang dan dapat mempengaruhi hasil belajar peserta didik dan tanggapan peserta didik untuk multimedia pembelajaran berbasis Multi Level Representasi (MLR) ini adalah baik dengan persentase sebesar 81,4\% (Nadhifah, 2019). 


\section{Metode Penelitian}

Penelitian ini dilaksanakan di MAN Kendal pada kelas XI MIPA Semester Genap Tahun Ajaran 2018/2019. Metode penelitian yang digunakan adalah penelitian eksperimen dengan rancangan Pretest-posttest Control Group Design pada Gambar 1 sebagai berikut:

$$
\begin{array}{cccc}
\mathrm{R}_{1}: & \mathrm{O}_{1} & \mathrm{X} & \mathrm{O}_{2} \\
\mathrm{R}_{2}: & \mathrm{O}_{3} & & \mathrm{O}_{4}
\end{array}
$$

\section{Gambar 1. Design Penelitian Pretest-posttest Control Group Design}

Waktu penelitian dilaksanakan dari bulan Mei sampai Juni 2019, dengan populasi penelitian adalah peserta didik kelas XI MIPA yang terdiri dari 6 kelas. Selanjutnya pengambilan sampel dilakukan dengan cara Cluster Random Sampling untuk menentukan 2 kelas yang akan dijadikan sampel penelitian, sehingga diperoleh kelas XI MIPA 3 yang terdiri dari 28 peserta didik sebagai kelas eksperimen dan kelas XI MIPA 1 yang terdiri dari 30 peserta didik sebagai kelas kontrol. Dimana kelas eksperimen diajarkan dengan menggunakan multimedia pembelajaran berbasis MLR, sedangkan kelas kontrol diajarkan dengan menggunakan buku pelajaran biasa dengan metode ceramah. Setelah perlakuan kedua kelas diberi tes prestasi belajar yang sama.

Instrumen tes yang digunakan adalah soal pretest/posttest dalam bentuk pilihan ganda. Sebelum digunakan dalam proses penelitian, soal dibuat sebanyak 50 butir soal. Selanjutnya diuji cobakan dan di analisis. Berdasarkan hasil analisis yaitu dari analisis validitas, reliabilitas, tingkat kesukaran dan daya beda soal yang terdapat pada Lampiran 8 dan 9, sera ditunujukan pada Tabel 1.2 dan 3 berikut :

\begin{tabular}{|c|c|c|c|}
\hline Kriteria & Nomor Soal & Jumlah & $\%$ \\
\hline \multirow{4}{*}{ Valid } & $1,2,4,6,9,11,12,17,18$ & \multirow{4}{*}{30} & \multirow{4}{*}{$60 \%$} \\
\hline & $20,22,23,24,25,26,27$ & & \\
\hline & $28,29,30,31,33,37,42$ & & \\
\hline & $43,44,45,46,47,48,50$ & & \\
\hline \multirow{4}{*}{$\begin{array}{l}\text { Tidak } \\
\text { Valid }\end{array}$} & $3,5,7,8,10,13,14$ & & \\
\hline & $15,16,19,21,32,34,35$ & 20 & $40 \%$ \\
\hline & $36,38,39,40,41,49$ & & \\
\hline & Jumlah & 50 & $100 \%$ \\
\hline
\end{tabular}

Tabel 1. Analisis Uji Validitas

Berdasarkan hasil analisis Tabel .1 diperoleh sebanyak 30 butir soal dinyatakan valid dan 20 butir soal dinyatakan tidak valid. Selanjutnya dari hasil perhitungan reliabilitas soal pada Lampiran 8 diperoleh $r_{11}=0,84$ dibanding $\quad r_{\text {tabel }}$ dengan taraf signifikan $5 \%$ dan $\mathrm{N}=50$ maka nilai $\mathrm{r}_{\text {tabel }}=0,28$, karena nilai $r_{11}>r_{\text {tabel }}$ maka soal tersebut dinyatakan reliabel.

Tabel 2. Hasil Analisis Tingkat Kesukaran Butir

\begin{tabular}{|c|c|c|c|}
\hline Kriteria & Nomor Soal & Jumlah & $\%$ \\
\hline Mudah & $\begin{array}{c}1,2,4,5,9,10,12, \\
15 \\
17,20,21,23,24 \\
25,26 \\
29,30,31,33,37 \\
42,43 \\
45,46,47,48,50\end{array}$ & 29 & $58 \%$ \\
\hline Sedang & $\begin{array}{c}3,6,7,11,18,19 \\
22 \\
27,28,32,35,44\end{array}$ & 12 & $24 \%$ \\
\hline Sukar & $\begin{array}{c}8,16,34,36,38 \\
39,40 \\
41,49\end{array}$ & 9 & $18 \%$ \\
\hline & Jumlah & 50 & $100 \%$ \\
\hline
\end{tabular}
Soal

Berdasarkan analisis Tabel 2 di atas, diperoleh sebanyak 29 butir soal termasuk dalam kriteria mudah dengan persentase 58\%, 12 butir soal termasuk dalam kriteria sedang dengan persentasi $24 \%$ dan 9 butir soal 
termasuk dalam kriteria sukar dengan persentase $9 \%$.

Berdasarkan analisis, diperoleh bahwa sebanyak 24 butir soal termasuk dalam kriteria daya beda soalnya jelek, 19 butir soal termasuk dalam kriteria daya beda soalnya cukup dan 7 butir soal termasuk dalam kriteria daya beda soalnya baik.

\section{HASIL DAN PEMBAHASAN}

Penelitian diawali dengan menentukan kelas eksperimen dan kelas kontrol terlebih dahulu menganalisis data populasi dengan cara uji normalitas dan homogenitas. Analisis data yang digunakan adalah nilai UTS semester genap tahun ajaran 2018/2019 dari keenam kelas XI MIPA yang ada di MAN Kendal. Berdasarkan hasil analisis data populasi pada Tabel 3 di bawah ini menunjukan bahwa keenam kelas tersebut dalam kondisi normal, homogen dan memiliki nilai rata-rata yang sama.

Tabel 3. Hasil Analisis Uji Normalitas Populasi

\begin{tabular}{cccc}
\hline Kelas & $\mathrm{X}^{2}$ hitung & $\mathrm{X}^{2}{ }_{\text {tabel }}$ & Keterangan \\
\hline XI MIPA 1 & 10.11 & 11.07 & Normal \\
XI MIPA 2 & 7.14 & 11.07 & Normal \\
XI MIPA 3 & 5.25 & 11.07 & Normal \\
XI MIPA 4 & 10.66 & 11.07 & Normal \\
XI MIPA 5 & 8.84 & 11.07 & Normal \\
XI MIPA 6 & 10.95 & 11,07 & Normal \\
\hline
\end{tabular}

Pada taraf signifikan 5\% dan $\mathrm{dk}=5$, maka diperoleh $X^{2}$ tabel $=11,07$. Berdasarkan tabel di atas dapat dilihat bahwa keenam kelas dapat disimpulkan bersistribusi normal, karena $X^{2}{ }_{\text {hitung }}<X^{2}$ tabel. Suatu populasi dikatakan homogen jika $F_{\text {hitung }}<F_{\text {tabel. }}$. Berdasarkan perhitungan pada Lampiran 16 diperoleh hasil $\mathrm{F}_{\text {hitung }}=1,67$. Pada taraf signifikan 5\%, dengan

86

Copyright (C) 2019 JEC | ISSN 2715-3029 (p) 2685-4880 (e)

Volume 1, Nomor 2, 2019 $\mathrm{dk}$ pembilang $=36 \mathrm{dan} \mathrm{dk}$ penyebut $=37$ diperoleh $\mathrm{F}_{\text {tabel }}=1,78$. Hasil ini menunjukan bahwa $F_{\text {hitung }}<F_{\text {tabel }}$ sehingga populasi dinyatakan homogen.

Berdasarkan perhitungan uji ANOVA data populasi dari nilai UTS, diperoleh hasil bahwa Fhitung $=0,000163$, dengan taraf signifikan 5\% dan $\mathrm{db}_{1}=5, \mathrm{db}_{2}=183$ diperoleh $\mathrm{F}_{\text {tabel }}=2,21$. Maka dapat disimpulkan bahwa Ho diterima dan Ha ditolak, dengan kriteria Fhitung $\leq F_{\text {tabel }}$ yang berarti populasi tersebut mempunyai nilai ratarata yang tidak berbeda atau sama.

Tahap penelitian selanjutnya adalah pemberian soal pretest pada kelas eksperimen dan kelas kontrol sebelum diberi perlakuan pada tiap sampel tersebut. Berdasarkan hasil analisis data awal yang diambil dari nilai pretest tersebut, diperoleh rata-rata nilai pretest seperti pada Tabel 5 dan Gambar 2 berikut:

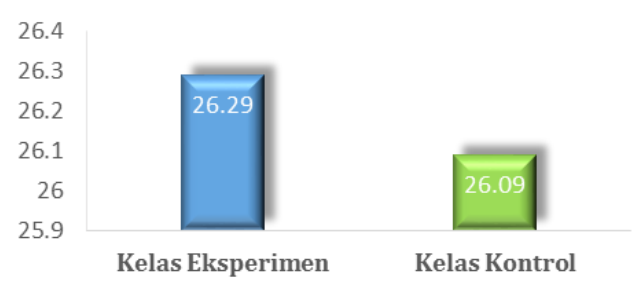

\section{Gambar 2 Grafik Perbedaan Rata-rata Nilai Pretest}

Berdasarkan hasil analisis dari Gambar 1 di atas, diperoleh data bahwa nilai rata-rata pretest kelas eksperimen yaitu sebesar 26,29 sedangkan nilai rata-rata pretest kelas kontrol yaitu sebesar 26,09.

Berdasarkan hasil analisis terhadap data posstest, diperoleh rata-rata nilai hasil belajar peserta didik kelas eksperimen lebih besar daripada rata-rata nilai hasil belajar peserta didik kelas kontrol. Adapun perbedaan rata-rata nilai hasil belajar peserta didik antara kelas eksperimen dan kelas kontrol dapat dilihat pada Tabel 6 dan Gambar 3 berikut: 


\section{Tabel 6 Nilai Rata-rata Posttest Kelas Eksperimen dan Kontrol}

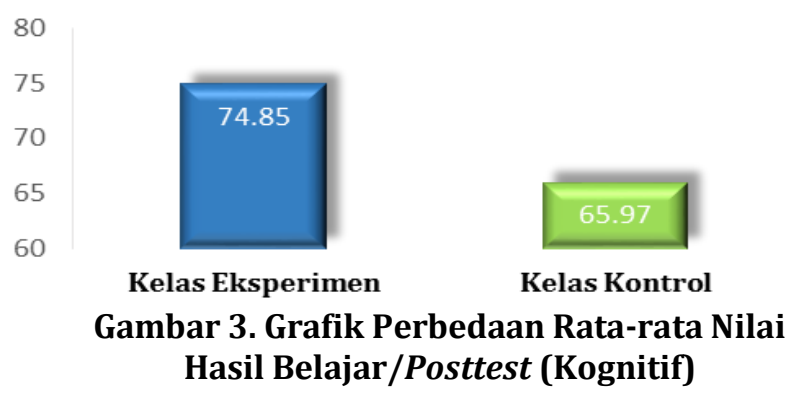

Dari gambar 2 diketahui bahwa nilai ratarata hasil belajar peserta didik kelas eksperimen sudah mencapai nilai KKM dengan nilai ratarata hasil belajarnya sebesar 74,85 dengan persentase ketuntasan mencapai 71\%, sedangkan kelas kontrol belum mencapai nilai KKM karena nilai rata-rata hasil belajarnya hanya sebesar 65,97 dengan persentase ketuntasan mencapai 33\%. Dari 28 peserta didik pada kelas eksperimen 20 peserta didik dinyatakan telah tuntas dengan nilai di atas 75 dan 8 peserta didik lainnya belum tuntas (nilai di bawah 75). Pada kelas kontrol hanya 10 peserta didik yang telah tuntas dari jumlah keseluruhan 30 peserta didik, sedangkan 20 peserta didik lainnya belum tuntas. Presentase ketuntasan hasil belajar yang diperoleh antara kelas eksperimen dan kelas kontrol dapat dilihat pada Gambar 4 berikut :

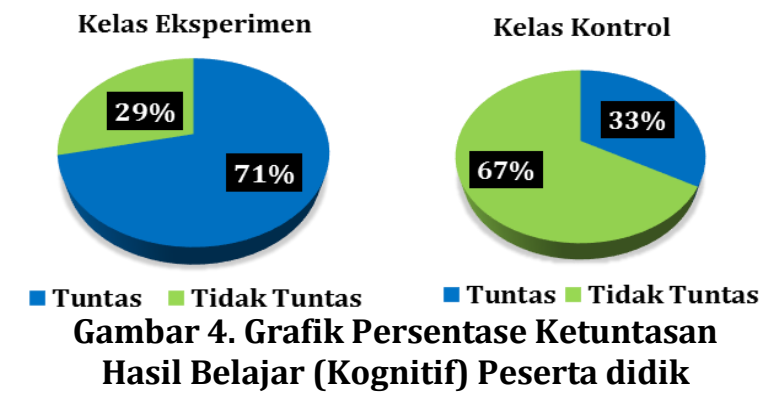

Selain hasil dari analisis pada Gambar 4.3 yang menunjukan bahwa adanya peningkatan pada nilai hasil belajar peserta didik yang signifikan antara kelas eksperimen dan kelas kontrol. Artinya hasil belajar yang diperoleh oleh peserta didik kelas eksperimen lebih baik daripada kelas kontrol.

Berdasarkan uji perbedaan rata-rata pada Tabel 4 berikut:

Tabel 4 Analisis Uji Dua Pihak

\begin{tabular}{ccc}
\hline \multirow{2}{*}{ Sumber Variasi } & \multicolumn{2}{c}{ Kelas } \\
\cline { 2 - 3 } & Eksperimen & Kontrol \\
\hline $\mathrm{X}$ & 1972,5 & 1868,8 \\
$\mathrm{X}$ & 74,85 & 65,97 \\
$\mathrm{~N}$ & 28 & 30 \\
Standar Deviasi & 9,70 & 7,17 \\
\multicolumn{3}{c}{4,475} \\
\hline $\mathrm{t}_{\text {hitung }}$ & \multicolumn{2}{c}{56} \\
\hline $\mathrm{Dk}$ & \multicolumn{2}{c}{2,003} \\
\hline $\mathrm{t}_{\text {tabel }}$
\end{tabular}

Hasil dari data di atas, diperoleh bahwa nilai $\mathrm{t}_{\text {hitung }}=4,475$, dengan taraf signifikan $5 \%$ dan $\mathrm{dk}$ $=56$ diperoleh $t_{\text {tabel }}=2,003$, hasil tersebut menunjukkan bahwa ada perbedaan antara rata-rata hasil belajar peserta didik kelas eksperimen dengan rata-rata hasil belajar peserta didik kelas kontrol. Kemudian dari analisis dengan uji pihak kanan, berdasarkan pada Tabel 5 berikut:

Tabel 5 Hasil Uji Pihak Kanan

\begin{tabular}{ccc}
\hline \multirow{2}{*}{ Sumber Variasi } & \multicolumn{2}{c}{ Kelas } \\
\cline { 2 - 3 } & Eksperimen & Kontrol \\
\hline $\mathrm{X}$ & 1972,5 & 1868,8 \\
$\mathrm{X}$ & 74,85 & 65,97 \\
$\mathrm{~N}$ & 28 & 30 \\
Standar Deviasi & 9,70 & 7,17 \\
\multicolumn{3}{c}{5,475} \\
\hline $\mathrm{t}_{\text {hitung }}$ & \multicolumn{2}{c}{57,76} \\
\hline $\mathrm{Dk}$ & \multicolumn{2}{c}{1,672} \\
\hline $\mathrm{t}_{\text {tabel }}$
\end{tabular}

Hasil dari uji pihak kanan tersebut, digambarkan dalam kurva pada Gambar 5 berikut : 


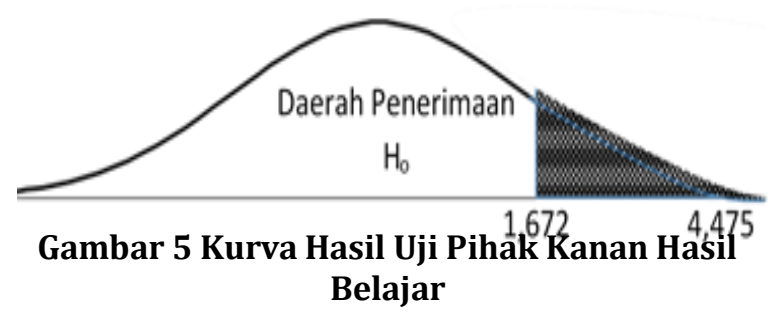

Berdasarkan data dari Tabel 4 dan Gambar 4 , dapat disimpulkan bahwa $t_{\text {hitung }}>t_{\text {tabel }}=4,475$ $>1,672$ dengan $\mathrm{dk}=57$ dan pada taraf signifikan $5 \%$. Artinya rata-rata hasil belajar peserta didik yang diajar menggunakan multimedia pembelajaran berbasis MLR pada pembelajaran kimia materi koloid lebih besar dari pada ratarata hasil belajar peserta yang diajar menggunakan media pembelajaran konvensional.

Hasil tersebut juga dikuatkan berdasarkan hasil uji N-gain, yang menunjukkan bahwa kelas eksperimen mengalami peningkatan hasil belajar yang cukup signifikan yaitu sebesar 0,66 yang termasuk kriteria sedang, dan kelas kontrol diperoleh nilai N-gain sebesar 0,54 yang termasuk kriteria sedang. Kedua nilai N-gain dari kedua sampel termasuk dalam kriteria sedang, namun nilai $\mathrm{N}$-gain untuk kelas eksperimen lebih besar daripada kelas kontrol. Artinya peningkatan hasil belajar peserta didik kelas ekperimen lebih baik daripada kelas kontrol. Hal ini dikarenakan instrumen tes yang digunakan lebih banyak mencakup pada tingakatan level makroskopik, simbolik serta beberapa pada level mikroskopik. Adapun peningkatan hasil belajar dari hasil uji N-gain antara kelas ekperimen dan kontrol dapat dilihat pada Gambah 5 berikut:

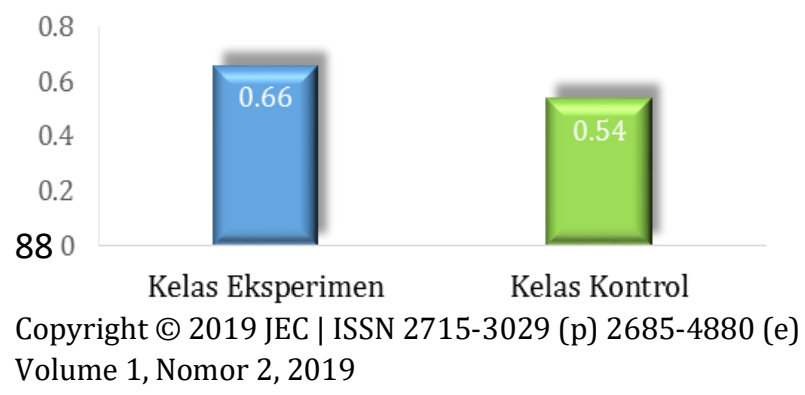

\section{Gambar 5 Grafik Perbedaan Nilai N-gain Hasil Belajar}

Bedasarkan dari beberapa uraian di atas, dapat disimpulkan bahwa proses pembelajaran kimia dengan mengunakan multimedia pembelajaran berbasis $M L R$ pada materi koloid dapat meningkatan hasil belajar peserta didik kelas XI MIPA di MAN Kendal.

Namun pada penelitian ini terdapat kendala dan kekurangan yaitu multimedia dan instrumen yang digunakan belum sepenuhnya mencakup atau mencerminkan tiga level representasi kimia. Dimana muatan pada tingkatan level mikroskopiknya masih sangat kurang, bahkan terkesan hanya menyajikan gambar saja atau tidak mengarahkan kepada peserta didik untuk berpikir pada level mikroskopiknya. Oleh karena itu, untuk peneliti berikutnya perlu menyusun instrumen tes yang memenuhi serta mampu mengukur indikator kemampuan dari MLR serta multimedia yang dikembangkan oleh peneliti sebelumnya, disarankan untuk dilakukan tinjauan ulang atau revisi terhadap muatan representasi pada level mikroskopik. Saran ini diberikan karena dipandang bahwa muatan MLR pada tingkatan mikroskopik hasil pengembangan tersebut belum dikatakan dapat memenuhi fungsi atau syarat MLR yang telah disarankan oleh Ainsworth.

\section{Simpulan}

Berdasarkan hasil penelitian yang sudah dilakukan, dapat disimpulkan bahwa:

1. Proses pembelajaran dengan menggunakan multimedia pembelajaran berbasis MLR efektif untuk diterapkan pada materi sistem koloid di MAN Kendal. Hal tersebut dibuktikan dengan adanya peningkatan terhadap hasil belajar peserta didik. Rata- 
rata nilai dari peserta didik yang diajarkan dengan multimedia pembelajaran berbasis MLR pada materi sistem koloid lebih baik yaitu sebesar 74,85 daripada dengan peserta didik yang diajarkan dengan media pembelajaran konvensional yaitu sebesar 65,97 .

2. Berdasarkan uji t-test diperoleh nilai $t_{\text {hitung }}$ sebesar 4,475 dengan taraf signifikan 5\% dan $\mathrm{dk}=56$ diperoleh ttabel $=2,003$. Karena nilai $t_{\text {hitung }}>t_{\text {tabel, }}$ maka $\mathrm{Ho}$ ditolak dan $\mathrm{Ha}$ diterima. Artinya ada perbedaan antara ratarata hasil belajar peserta didik kelas eksperimen dengan rata-rata hasil belajar peserta didik kelas kontrol, dan dari hasil uji pihak kanan diperoleh $t_{\text {hitung }}>t_{\text {tabel }}=4,475>$ 1,672 dengan $\mathrm{dk}=57$ dan pada taraf signifikan 5\%. Artinya rata-rata hasil belajar peserta didik menggunakan multimedia pembelajaran berbasis $M L R$ lebih besar atau lebih baik dari

pada rata-rata hasil belajar peserta didik menggunakan media pembelajaran konvensional. Berdasarkan hasil analisis tingkat efektifitas hasil belajar pada ranah kognitif menunjukkan hasil rata-rata nilai $\mathrm{N}$ gain kelas eksperimen tingkat efektifitasnya sebesar 0,66 (sedang) dan pada kelas kontrol sebesar 0,54 (sedang).

\section{Referensi}

Achmaliya, N. 2016. Pengembangan Modul Berbasis Representasi Kimia Pada Materi Teori Tumbukan. Lampung: Universitas Lampung. Jurnal Pendidikan dan Pembelajaran Kimia, 5 (1) : 114-127.

Anonim. 2019. Perkembangan Kemampuan Kognitif. Diakses di https://www.brainfit.co.id/kemampuanko gnitif/ tanggal 09 April 2019

Anonim. 2019. Skripsi Bab II. Diakses di http://eprints.ung.ac.id tanggal 28 Mei
2019

Anonim. 2019. Skripsi Bab II. Diakses di http://eprints.uny.ac.id tanggal 28 Mei 2019

Arikunto, S, 2010, Dasar-dasar Evaluasi Pendidikan, Jakarta : Bumi Aksara

Arikunto, S, 2011, Dasar-dasar Evaluasi Pendidikan, Jakarta : Bumi Aksara

Badri, S. 2012. Metode Statistika Untuk Penelitian Kuantitatif. Yogyakarta : Penerbit Ombak

Chang, R, 2004, Kimia Dasar : Konsep -konsep Inti Jilid 1 Edisi Ketiga, Jakarta : Penerbit Erlangga.

Depdiknas. 2003. Kurikulum 2004, Standar Kompetensi Mata Pelajaran Kimia SMA dan $M A$. Jakarta : Departemen Pendidikan Nasional

Fathono, A. 2005. Metodologi Penelitian dan Teknik Penyusunan Skripsi. Jakarta: Rineka Cipta.

Hake, R. R. 1999. Analyzing Change/ Gain Scores. USA: Dept. of Physics Indiana University.

Hasanah, A, Murni dan Vodelf. 2017. Pembelajaran Berbasis Multiple Representasi. Sumatera Barat: Universitas Negeri Padang.

Herawati, R.F. 2013. Pembelajaran Kimia Berbasis Multiple Representasi Ditinjau dari Kemampuan Awal terhadap Prestasi Belajar Laju Reaksi Siswa SMA Negeri I Karanganyar Tahun Pelajaran 2011/2012. Jurnal Pendidikan Kimia (JPK), 2(2) : 38-43.

Kurniawan, A. H. 2012. Pengaruh Kemampuan Koginitif Terhadap Kemampuan Psikomotorik Mata Pelajaran Produktif Alat Ukur Siswa Kelas X Jurusan Teknik Kendaraan Ringan Di SMK Muhammadiyah Prambanan. Yogyakarta : UNY.

Kustandi, C. dan Bambang, S. (2011). Media Pembelajaran Manual dan Digital. Jakarta: Ghalia Indonesia.

Linda. R. 2016. Development of Lectora Inspire as Interactive Multimedia Chemistry Learning in Senior High School.J.Pendidikan Kimia. 8 (3) : 188-196 
Langitasari, I. 2016. Analisis Kemampuan Awal Multi Level Representasi Mahasiswa Tingkat I pada Konsep Reaksi Redoks. EduChemia, 1 (1) : 14-24

Lolombulan, J.H. 2017. Statistika Bagi Peneliti Pendidikan. Yogyakarta : CV. ANDI OFFSET

Mayer, R. E. 2003. "The Promise of Mulitmedia Learning: Using the Same Instructional Design Methods Across Different Media". Learning and Instruction, 13, 125- 139.

Mujakir. 2017. Pemanfaatan Bahan Ajar Berdasarkan Multi Level Representasi untuk Melatih Kemampuan Siswa Menyelesaikan Masalah Kimia Larutan. J. Lantanida. 5 (2) : 93-196.

Muharoroh. 2015. Tingkat Efektifitas Model Pembelajaran CORE (Connecting, Organizing, Reflecting and Extending) Bermuatan MLR (Multiple Level Representation) pada Materi Tata Nama Alkana, Alkena dan Alkuna di SMA Islam Al-Hikmah Mayong Jepara. Semarang : UIN Walisongo Semarang

Mulyasa. 2003. Manajemen Berbasis Sekolah, Bandung: PT Remaja Rosdakarya

Munir. 2012. Multimedia Konsep \& Aplikasi dalam Pendidikan. Bandung : Alfabeta.

Nadhifah, 2019, Pengembangan Multimedia Pembelajarn Berbasis Multi Level Representasi pda Materi Koloid Kelas XI MAN Kendal, Semarang : UIN Walisongo Semarang

Purwanto, A. 2016. Multimedia Pembelajaran Bahasa Indonesia Untuk Mahasiswa Berbasis Animasi. Jurnal Sistem dan Informatika, 11(1) : 51-58.

Ramadhani, D. G., Mulyani, B., Utomo, S. B. 2016. Pengaruh Penggunaan Media Mobile Learning Berbasis Android dan LKS Dalam Model Pembelajaran Student Team Achivement Division (STAD) Terhadap Prestasi Belajar Ditinjau Dari Kemampuan Memori Pada Materi Sistem Koloid Kelas XI SMAN 2 Purwokerto Tahun Ajaran
2015/2016, Surakarta : Universitas Sebelas Maret

Shalikhah, N. D. 2016. Pemanfaatan Aplikasi Lectora Inspire sebagai Media Pembelajaran Interaktif. J. Cakrawala 9(1) :101-115

Sari, D. J. 2017. Efektivitas e-book Interaktif Asam Basa Berbasis Representasi Kimia dalam Meningkatkan Pemahaman Konsep. Jurnal Pendidikan dan Pembelajaran Kimia, 7(2) : 237-250

Sofyan, A., Feronika, T., dan Milama, B. 2006, Evaluasi Pembelajaran IPA Berbasis Kompetensi, Jakarta : UIN Jakarta Press

Sudarmo, U. 2013. Kimia untuk SMA/MA Kelas XI. Surakarta : Erlangga

Sudjana, N. 2012. Penilaian Hasil Proses Belajar Mengajar. Bandung : PT. Remaja Rosdakarya

Sudjiono, A, 2011, Pengantar Evaluasi Pendidikan, Jakarta : Rajawali Pers

Sugiyono, 2010, Metode Penelitian Pendidikan (Pendekatan Kuantitatif, kualitatif, dan $R n D)$, Bandung: Alfabet

Sugiyono. 2003, Statistika untuk Penelitian. Bandung: Alfabeta

Sukmadinata, N. S. 2010. Metode Penelitian Pendidikan. Bandung: Remaja Rosdakarya

Sunyono. 2012. Kajian Teoritik Model Pembelajaran Kimia Berbasis Multipel Representasi (Simayang) Dalam Membangun Model Mental. Prosiding Seminar Nasional Kimia. 15 Januari 2012. Universitas Negeri Surabaya

Suprihatiningsih. J. 2014. Strategi Pembelajaran: Teori dan Aplikasi, Jogjakarta: Ar-Ruzz Media

Surjono, H. D. 2017. Multimedia Pembelajaran Interaktif : Konsep dan pengembangan. Yogyakarta: UNY Press

Sutresna, N. 2014. Advanced Learning : Chemistry 2B for Grade XI Senior High School. Bandung: Grafindo Media Pratama Trianto. 2012. Mendesain Model Pembelajaran

90

Copyright (C) 2019 JEC | ISSN 2715-3029 (p) 2685-4880 (e)

Volume 1, Nomor 2, 2019 
Inovatif-Progresif. Jakarta: Kencana Prenada Media

Winarni. 2017. Pengembangan Modul Pembelajaran Kimia Berbasis Multipel Representasi Pada Materi Laju Reaksi Kelas XI IPA 1 SMA Panca Bhakti Pontianak. Pontianak : Pendidikan Kimia, Universitas Muhammadiyah Pontianak

Yuliana, D. 2018. Efektivitas LKS Berbasis Multipel Representasi dalam Meningkatkan Penguasaan Konsep Materi Larutan Elektrolit-Non Elektrolit. Bandar Lampung: Universitas Lampung 